\title{
Justyna Czort*
}

\author{
Akademia Ignatianum w Krakowie
}

\section{W POGONI ZA NIEUTRACONĄ WYOBRAŹNIA}

\section{Abstract \\ In the pursuit of an unreleased imagination}

Imagination, both childish and adult, is usually perceived positively. However, it often happens that with age, this still mysterious ability to go beyond the real world disappears. Then we often become skeptical and even irritated by the younger confreres around us, who are lively talking about terrible dragons and wonderful princesses. Escape from our own imagination may be caused by the mistaken belief that we no longer deserve a little better world. On the other hand, we forget that imagination has not only a bright side, but also a dark side, which children remember perfectly. However, there are adults among us who not only have not forgotten about this mysterious attribute, but also use it when it is most needed.

Key words: childhood, world of children's imagination, adulthood

Kiedy po całym dniu żmudnych starań i wykonywania codziennych obowiązków siadam w moim upragnionym miejscu przy oknie w tramwaju, a obok mnie usadawia się jakieś rozkrzyczane dziecko, które - jak się zdaje - bardzo chce pochwalić się wszystkimi umiejętnościami rozmowy z mamą, bardzo się irytuję. I wręcz zła jestem na siebie, że się irytuję. Przecież co taki maleńki szkrab winny temu, że jeszcze tak żywo się emocjonuje wszystkim, co go otacza. Czemu winne były szkraby, do których Julian Tuwim, gdyby tylko jeszcze żył, mógłby krzyknąć: „Czemu powtarzasz z pasją upartą To dzikie słowo, zmyślone słowo: «Tere-bere, tere-bere!»"? (Tuwim 1979: 131). Chyba tylko temu, że mogą żyć beztrosko, czyli robić to, na co tylko mają ochotę, bez szczególnych konsekwencji. Poeta w Wierszu wyszydzającym dzieci, jak sam tytuł wskazuje, naśmiewa się z zachowań najmłodszych, jednocześnie uwypuklając ich niedoskonałości związane z wyglądem zewnętrznym. Przez kąśliwe uwagi pod ich adresem przepływa poirytowanie, a nawet agresja. W drugiej części utworu jesteśmy świadkami nieudolnej próby przestraszenia dzieci przez Tuwima, który wspomina o pojawieniu się przerażającego księżyca czy

\footnotetext{
* Studentka jednolitych studiów magisterskich na kierunku psychologia na UJ.
} 
olbrzymiego psa. Jednak to straszenie w wykonaniu poety ze względu właśnie na swą nieudolność ma charakter zabawny, który niewątpliwe łagodzi wytworzony przez czytelnika obraz jego nastawienia do dzieci.

Wydaje mi się, że często nasze niestosowne zachowania wobec tych najbardziej niewinnych członków naszego społeczeństwa wynikają z tęsknoty - tęsknoty za bezpowrotnym światem marzeń i fascynujących zabaw. Pamiętam taki słoneczny dzień, kiedy jeszcze miałam okazję cieszyć się z przywilejów bycia dzieckiem. Zwyczajny spacer $\mathrm{z}$ mamą osiedlową alejką. Minęlyśmy wtedy dwie nastolatki żywo rozprawiające o jakichś miłosnych rozterkach. Nigdy nie zapomnę tego, jak bardzo wtedy chciałam wyglądać, zachowywać się i mieć takie problemy jak one. Niebezpodstawnie krąży po świecie przekonanie, że człowiek ma to do siebie, że zawsze chce tego, czego nie ma. Bardzo słuszne to stwierdzenie, bo teraz chciałabym powrócić do tych dziecięcych lat. Do lat, w których nie liczyło się dni, a jedynym licznikiem czasu, jaki przykładowo spędzało się na zewnątrz, był głos mamy nawołujący do powrotu do domu, kiedy już się ściemniało.

O beztroskich zabawach na dworze wspomina Józef Baran w swoim wierszu zatytułowanym Zabawa (Baran 1979). Poeta przywołuje w utworze swoje wspomnienie podwórkowej zabawy w państwo, w której to każdy przybierał określone role: króla, błazna, bandyty, robotnika, żołnierza, urzędnika. Niestety, po jakimś czasie po śmiechu wartej zabawie zostało już niewiele: król całymi dniami siedział dumnie na swoim tronie, policjant stał się sztywny i zaczął gonić bandytę, który wskutek tego zaczął przed nim uciekać, a robotnik pracował od rana do nocy. Tylko jeden błazen nawoływał do wszystkich, że to tylko zabawa, lecz pozostali myśleli, że jest obłąkany. W istocie, kiedy jesteśmy dziećmi, Gombrowiczowskie maski znane są nam jedynie z zabaw. Kiedy stajemy się dorośli, przyjmujemy określone role, bo tego się od nas wymaga, bo to jednoznaczne z dojrzałością. Kogoś, kto widzi i wie więcej o sobie i o nas samych, nazywamy obłąkanym. Wiersz ten - oprócz tego, że uzmysławia nam bolesne skutki dorastania pomaga zrozumieć, dlaczego tak wielu dorosłych nie traktuje swoich pociech w pełni poważnie. Dorośli często uważają, że godna praca to jeden z głównych wyznaczników szczęśliwego życia. I o ile wydaje mi się, że w dzisiejszym świecie coraz więcej z nich zauważa, że jednak tak nie jest, o tyle niewielu potrafi z tym coś zrobić.

Gdy przywołuję postaci z wiersza Józefa Barana, po głowie zaczyna mi uciążliwie chodzić Mały Książę (Saint-Exupéry 2015). Kiedy sięgnę pamięcią do lat szkoły podstawowej, w której to obowiązkowo mieliśmy czytać tę książkę, przypominam sobie, że niewiele z niej zrozumiałam, aczkolwiek bardzo mi się podobała. Niedawno postanowiłam do niej wrócić i jak łatwo się domyślić, dopiero teraz wszystko stało się jasne. Kiedyś zastanawiałam się, dlaczego właściwie Mały Książę zdecydował się umrzeć. Teraz wydaje mi się, że już wiem. Nawet na jego własnej planecie nie było miejsca dla jego dziecięcej wrażliwości, empatyczności i niesamowitej mądrości, większej od tej, którą posiedli dorośli. Chociaż Mały Książę po odwiedzeniu różnych asteroid zamieszkiwanych przez: Króla, Próżnego Pana, Pijaka, Biznesmena, Geografa, Latarnika raczej w tę mądrość dorosłych powątpiewa. Jednakże myślę, że był w jego życiu jeden dorosły, którego postrzegał za mądrego. Był nim Lotnik. Miał on co prawda całą masę cech, 
jakimi przystało dysponować dorosłemu, ale skutecznie konfrontował je z dzieckiem, które gdzieś jeszcze w jego głębi żyło. Mężczyzna na początku nie rozumiał swojego jasnowłosego przyjaciela, nie wiedział, czemu został poproszony o narysowanie baranka oraz dlaczego tak interesowała go kwestia posiadania przez kwiaty kolców. Pilot starał się jednak zrozumieć. A może wcale się nie starał? Może on w rzeczywistości rozumiał? Może Mały Książę był tylko przyjacielem żyjącym w jego głowie. To by oznaczało, że dorośli także mają wyobraźnię. Myślę, że każdy ją ma. Wszystko zależy od tego, na ile pozwolimy jej wydostać się z czeluści naszego umysłu.

Kiedy jednak jest się dzieckiem, o żadnym uwalnianiu wyobraźni z czeluści umysłu nie ma mowy. Żaden normalny kilkulatek nie zastanawia się, kiedy i w jakim stopniu może jej użyć. Po prostu to robi. Nie zawsze jednak dzieci dają upust swojej wyobraźni, tworząc miły i przyjazny świat wróżek, krasnoludków czy elfów. Często po przeczytaniu strasznej bajki bądź obejrzeniu kreskówki, której głównym bohaterem jest gadający kościotrup, w głowach najmłodszych powstają mroczne obrazy, które urzeczywistniać lubią się szczególnie w nocy. Właśnie przez wzgląd na nie Włodzimierz Słobodnik w swoim wierszu Symfonia dziecięca apeluje, że dzieciństwo wcale nie jest czasem bezpiecznym i kolorowym. Poeta wspomina, że dziecko może odbierać otaczającą go rzeczywistość jako świat pełen czających się czarownic, diabłów, potworów. Nawet tak trywialna czynność, jak spuszczenie wody w toalecie może przynieść wiele niepokoju: „W klozecie, kiedy spuszczasz wodę, diabeł siedzi I chichocze obleśnie jak spuszczana woda” (Słobodnik 1979: 157) Dzieci są także dręczone przez koszmary nocne, w których głównymi bohaterami są kruki o twarzach morderców, garbate ludziki dręczące zwierzęta czy gwiazdy torturowane przez złe anioły.

Autor podkreśla także, że to dzieci mają otwarte oczy na najgorszą nieprawdę naszej ziemi. Stąd też ich niekontrolowane wybuchy płaczu i strachu, które spotykają się z brakiem zrozumienia przez niezauważających tych przedziwnych zjawisk dorosłych. Zostaje także zwrócona uwaga na erotykę dziecka przyrównaną do pierwszych traw i wiosennych liści. Erotykę tę przedstawia poeta jako nieco zaburzoną, gdyż chłopiec w głaszczącej go matczynej dłoni dopatruje się dłoni kochanki. Takie zachowanie przypomina mi pewien szokujący film Kuby Czekaja Baby Bump (2015). Jego bohaterem jest jedenastoletni chłopiec o pseudonimie Mickey House. Mickey przechodzi przez bardzo dla niego trudny okres dorastania - zauważa, że jego ciało zaczyna się zmieniać. W dodatku nie ma kolegów w szkole, a wsparcia nie może znaleźć nawet w domu, jego matka zdaje się bowiem nie zauważać, że syn powoli staje się mężczyzną, i obdarowuje go dużą dozą fizycznej troskliwości. Matka jest kobietą atrakcyjną, co jeszcze bardziej przyczynia się do siania zamętu w głowie chłopca. Należy również dodać, że Mickey wychowuje się bez ojca. Chłopiec nie radzi sobie z sytuacją w domu i w szkole, dlatego żyje w świecie swojej wyobraźni, w której każdy dzień stawia przed nim jakąś misję. Do misji tych należy przykładowo zebranie pieniędzy na operację uszu. Aby zrealizować swój cel chłopak sprzedaje mocz kolegom zażywającym narkotyki. Sam film jest bardzo kolorowy i ma formę nałożonych na siebie warstw obrazów, słów i muzyki. Żywym aktorom towarzyszą anonimowe postaci. Właśnie forma filmu pokazuje, jak Mickey widzi otaczające go środowisko. Przykładowo jego rówieśnicy, którym sprzedaje mocz, 
to w oczach chłopca groźnie ubrana szajka mieszkająca wspólnie we własnym domu. Wyraźnie widać, że obraz rzeczywistości, jaki tworzy, jest podyktowany niemożnością poradzenia sobie ze światem rzeczywistym.

Zresztą zazwyczaj, kiedy źle się dzieje, wiele osób ucieka do swojego świata. Bo kiedy życie jest za ciężkie, a pomysłów na rozwiązanie problemów brak, trzeba sobie przecież jakoś radzić. Były wokalista zespołu Myslovitz Artur Rojek w swojej książce pt. Inaczej uchyla rąbka tajemnicy swojego dzieciństwa. Artur swe najmłodsze lata spędził na Śląsku, w małym miasteczku Mysłowice. Swoje dzieciństwo opisuje jako spokojne, ale chwilami smutne. Nie był dobrze traktowany przez swoich rówieśników, którzy wyśmiewali się z jego nazwiska i profesji rodziców. A mały muzyk znosił krytykę bardzo źle i bił się z kolegami, za wszelką cenę walcząc, aby nie stać się ofiarą. Obecnie Rojek jest znany ze swojej poruszającej, niesamowicie nacechowanej emocjami muzyki. Artysta deklaruje, że często pisze o własnych emocjach, bo to wydaje mu się najszczersze. Do jednego z najbardziej alternatywnych projektów muzycznych, jakie stworzył, należy Lenny Valentino. Jedna z piosenek zatytułowana została Chłopiec z plasteliny. Na początku wszystko w świecie chłopca wydaje się takie, jak powinno być: dziadek głaszcze go po głowie, chłopiec je tort z okazji swoich urodzin, w swoim pokoju ma dużo misiów i pościel w gwiazdki. Okazuje się jednak, że za oknem dziecko widzi chudą żyrafę i ślepego słonia, a jego przyjaciele kradną jabłka $\mathrm{z}$ drzew. Nie wiem, czy kradzież jabłek z drzew jest synonimem konfliktów z kolegami, ale o zwierzętach widzianych za oknem sam Rojek wspomina jako o metaforze smutku.

Smutek, zawód, lęk i strach są więc wpisane w życie nawet najmłodszych z nas. I choć wiele jest w literaturze przykładów tego, że to dzieci radzą sobie z tymi emocjami za pomocą wyobraźni, jednak wydaje mi się, że dorośli też często uciekają do tego bezpiecznego świata. A słuchając niektórych utworów Myslovitz, których często teksty są bardzo abstrakcyjne, wydaje mi się, że w ich twórcach na pewno ta dziecięca wrażliwość i marzycielskość pozostała.

\section{Bibliografia}

Baran J. (1979). Zabawa, w: J. Nagrabiecki (oprac.), Dziecku wybór wierszy. Ludowa Spółdzielnia Wydawnicza, Warszawa: 356-358.

Chłopiec z plasteliny, w: Lenny Valentino; https://www.polskirock.eu/chlopiec-z-plasteliny,lenny-valentino,6074,plyta.html (dostęp: 21.01.2020).

Czekaj K. (reż.) (2015). Baby bump. Film. Prod. Polska, Włochy, 90 min.

Rojek A. (2015). Inaczej. Agora, Warszawa.

Saint-Exupéry A. de (2015). Mały Książe, tłum. J. Szwykowski. Wydawnictwo Algo, Toruń.

Słobodnik W. (1979). Symfonia dziecięca, w: J. Nagrabiecki (oprac.), Dziecku wybór wierszy. Ludowa Spółdzielnia Wydawnicza, Warszawa: 157-159.

Tuwim J. (1979). Wiersz wyszydzający dzieci, w: J. Nagrabiecki (oprac.), Dziecku wybór wierszy. Ludowa Spółdzielnia Wydawnicza, Warszawa: 131-132. 